\title{
Phototherapy in Allergic Rhinitis: From In Vitro Studies to Clinical Trials
}

\author{
Shin Hyuk Yoo ${ }^{1,2}$ \\ Young-Jun Chung ${ }^{1,2}$ \\ Jun-Sang Bae ${ }^{1,2}$ \\ Ji-Hun $\mathrm{Mo}^{1,2,3}$
}

\footnotetext{
${ }^{1}$ Department of Otorhinolaryngology and ${ }^{2}$ Beckman Laser Institute Korea, Dankook University College of Medicine, Cheonan, Korea ${ }^{3}$ Laser Translational Clinical Trial Center, Dankook University Hospital, Cheonan, Korea
}

\footnotetext{
Correspondence

Ji-Hun Mo

Department of Otorhinolaryngology, Dankook University College of Medicine, 201 Manghyangro, Dongnam-gu, Cheonan 31116, Korea

Tel.: +82-41-550-3933

Fax: +82-41-556-1090

E-mail: jihunmodgmail.com

(c) Korean Society for Laser Medicine and Surgery

(@) This is an open access article distributed under the terms of the Creative Commons Attribution NonCommercial License (http://creativecommons.org/ licenses/by-nc/4.0) which permits unrestricted noncommercial use, distribution, and reproduction in any medium, provided the original work is properly cited.
}

\begin{abstract}
Phototherapy has a profound immunosuppressive effect and is widely used for the treatment of inflammatory skin diseases. Since allergic rhinitis (AR) shares several common pathologic features with atopic dermatitis, intranasal phototherapy is a novel approach for treating AR. Phototherapy reduces the antigen presenting capacity of dendritic cells, induces apoptosis of immune cells, and inhibits synthesis and release of pro-inflammatory mediators from inflammatory cells. The effectiveness of phototherapy for AR has been extensively researched: from in vitro studies to several clinical trials. Data indicates the potential of intranasal phototherapy as an alternative treatment for AR as well as other inflammatory mucosal diseases. In this review, we introduce the in vitro, in vivo studies, and clinical trials which demonstrated the effect of phototherapy on AR.
\end{abstract}

\section{Key words}

Phototherapy; Allergic rhinitis; Laser; Low-level laser therapies 


\section{INTRODUCTION}

Allergic rhinitis (AR) is an IgE-mediated allergeninduced inflammatory disease of the nasal mucosa. ${ }^{1}$ Symptoms of AR include rhinorrhea, sneezing, itching and nasal obstruction. ${ }^{2}$ The prevalence of AR is increasing worldwide. It is experienced by $10-25 \%$ of the world's population, and approximately 60 million people are affected in the United States. ${ }^{3}$

Several treatment modalities have been tried to control AR including avoidance, medications, and immunotherapy. However, some patients with AR cannot be controlled properly. Antihistamines and topical nasal decongestants are generally used as the primary medications for AR. Antihistamines are effective for sneezing, runny nose and itching, but the effectiveness is uncertain for nasal obstruction. ${ }^{4}$ Topical decongestants can cause drug-induced rhinitis when used for a long time. ${ }^{5}$ Few patients with AR achieve complete symptomatic improvement through medical treatment, and medical treatment is limited in patients with special circumstances such as pregnant women or lactating mothers. ${ }^{6}$ Thus, several novel therapeutic modalities have been investigated.

Phototherapy was first identified in 1903 by Finsen, and its immunosuppressive effect was confirmed. ${ }^{7}$ Traditionally, phototherapy has been developed by dermatologists. It has been widely used for various inflammatory skin diseases such as atopic dermatitis. 8.9 As AR shares several common pathologic features with atopic dermatitis, it is also expected to be able to improve AR symptoms which are not controlled by medications with intranasal photo- therapy.

Thus, we are motivated to highlight the recent researches endeavored to alleviate AR through phototherapy. For this, we first introduce the in vitro and in vivo studies which demonstrated the effect of phototherapy on AR. Then we detail the various clinical trials which evaluated the efficacy of phototherapy on AR patients.

\section{EFFECT OF PHOTOTHERAPY ON IMMUNE CELLS: IN VITRO STUDIES}

As phototherapy has a profound immunosuppressive effect, it is widely used for the therapy of various inflammatory skin diseases such as psoriasis and atopic dermatitis. ${ }^{8-11}$ It is able to inhibit the effector phase of the allergic reaction at multiple points (Fig. 1). Several studies have investigated the effect of phototherapy on basophils, mast cells, eosinophils and T cells in vitro.

Ultraviolet A (UVA) irradiation exerts a biphasic dosedependant action on histamine release from human basophils incubated with an anti-lgE serum in vitro. ${ }^{12} \mathrm{At}$ the lowest irradiation doses $\left(<5 \mathrm{~J} / \mathrm{cm}^{2}\right)$, it has an inhibitory effect while the highest doses $\left(10 \mathrm{~J} / \mathrm{cm}^{2}\right)$ significantly increase histamine release. This study demonstrated that phototherapy, especially low dose UVA irradiation has inhibitory effect of histamine releases from basophils and mast cells. UVA doses less than $7.5 \mathrm{~J} / \mathrm{cm}^{2}$ could stabilize the cytoplasmic/granular membranes of basophils or modify the degranulating chemical signals giving rise to an inhibitory effect on the histamine release. High dose UVA irradiation could damage cell membranes, increas-

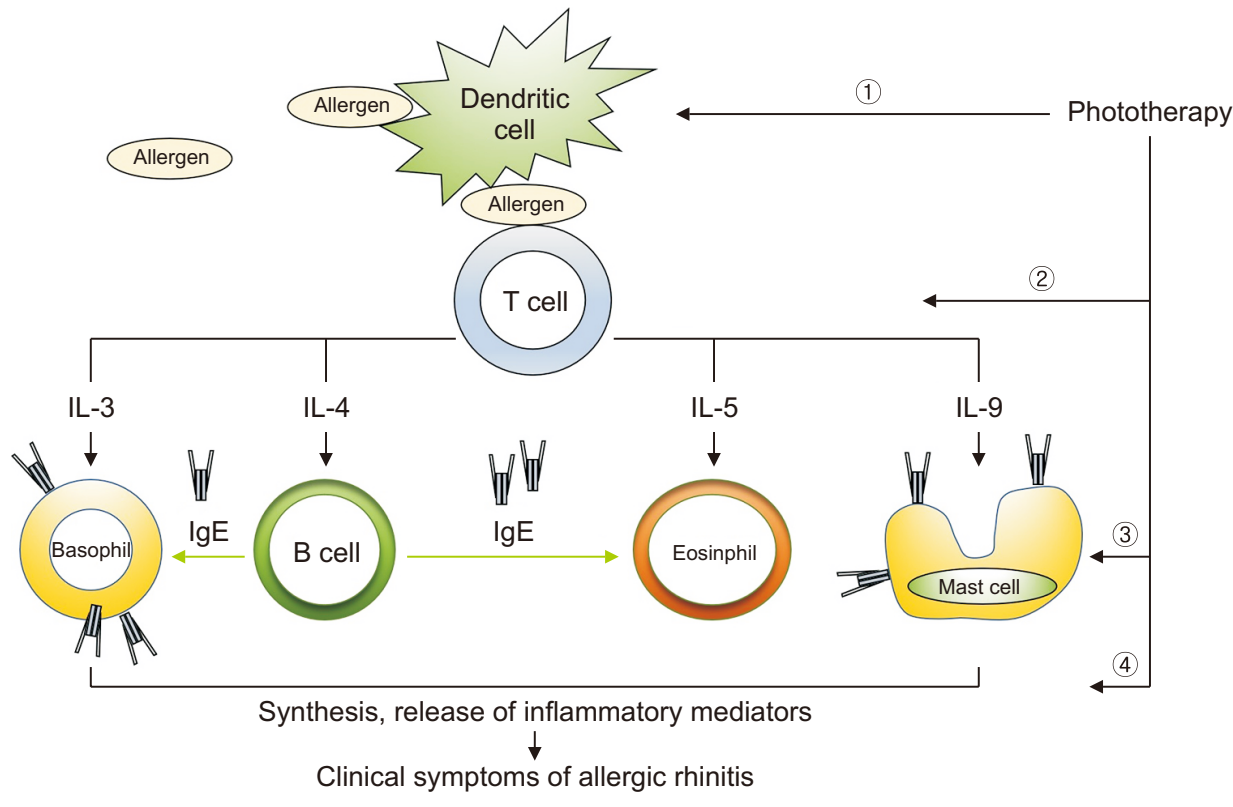

Fig. 1. Mechanism of action of phototherapy in allergic rhinitis. Phototherapy can improve clinical symptoms of allergic rhinitis (1) by reducing the antigen presentation of dendritic cells, (2) by inhibition of T cells, (3) by inducing apoptosis of immune cells, (4) by inhibiting synthesis and release of proinflammatory mediators from immune cells. 
ing histamine release.

Koreck et al. evaluated in vitro effect of mUVNIS (combination of ultraviolet B (UVB) (5\%), UVA (25\%), and visible light (70\%)) on AR. ${ }^{13}$ In vitro irradiation of eosinophils and T cells with mUVNIS light dose dependently induced apoptosis. Furthermore, mUVNIS irradiation inhibited the mediator release from rat basophils.

Krönauer and colleagues analyzed the influence of different ultraviolet (UV) wavelengths on histamine release from human basophils and mast cells. ${ }^{14}$ Enriched human basophils and human mast cells were irradiated with UVB, UVA and UVA1 in vitro. UVA and UVA1 significantly inhibited histamine release from basophils and mast cells. UVB only had an inhibitory effect on mast cells.

In one study, effect of infrared laser irradiation on interleukin (IL)-4 expression in Th2 cells was evaluated. ${ }^{15}$ Low power laser irradiation of $658 \mathrm{~nm}$ infrared wavelength with $2 \mathrm{~J} / \mathrm{cm}^{2}$ ( 640 seconds of duration) showed significant decreased expression level of IL-4 mRNA level compared with control group in the murine thymic lymphoma Th2 cells.

\section{EFFECTS OF PHOTOTHERAPY ON AR: IN VIVO STUDIES WITH ANIMAL MODELS}

\section{Animal model for AR}

Many researchers have used the mouse models of AR. In the fields of allergic disease, several models such as allergic asthma, allergic contact dermatitis, and AR are introduced, and several modifications are used. AR mouse models were developed and modified from allergic asthma model. ${ }^{16}$ Ovalbumin, house dust mite and fungus are most frequently used allergens. Usually, mice are sensitized with allergen and adjuvant such as aluminum hydroxide gel for 2-3 weeks (once/week) then are challenged with allergen intranasally every day for 1 week. ${ }^{17}$

Mice are sacrificed within 24 hours after final challenge. Several parameters of AR are usually evaluated: nasal rubbing, sneezing count, eosinophil count in the nasal mucosa, total and allergen specific lgE, nasal cytokine level and splenic cytokine level by splenocyte culture. By revealing those parameters, researchers could identify the allergic status of the mice. ${ }^{18}$ However, there are many variables in AR mouse model: mouse strain, type of allergen, sensitization time, adjuvant, acute or chronic type, and allergen administration route.

\section{Laser treatment in AR mouse models}

In vivo studies demonstrated effectiveness of phototherapy in AR mouse model were summarized in Table 1. Choi et al. investigated effects of low-level laser treatment (LLLT) on ovalbumin-induced AR mouse (Balb/c) model. ${ }^{15}$ With power output $30 \mathrm{~mW}$ and $658 \mathrm{~nm}$ wavelength laser, continuous irradiation was done for 320/640 seconds (1 $\mathrm{J} / \mathrm{cm}^{2}, 2 \mathrm{~J} / \mathrm{cm}^{2}$ ) intranasally. LLLT significantly inhibited total IgE, IL-4, and thymus and activation regulated chemokine (TARC) expression in ovalbumin-induced AR mice at low dose irradiation. The protein expression level of IL-4 in spleen was inhibited in low dose irradiation significantly.

In one recent study, anti-allergic effect of LLLT at 650 $\mathrm{nm}$ in ovalbumin induced AR mouse model was evaluated. ${ }^{19}$ LLLT exerted an antiallergic effect by decreasing local/systemic IL-4, IL-17, and IgE levels, as well as eosinophilic infiltration into the nasal mucosa, in an AR mouse model by modulating reactive oxygen species (ROS) and

Table 1. In vivo studies with animal models evaluated effectiveness of phototherapy on allergic rhinitis/asthma

\begin{tabular}{|c|c|c|c|c|c|}
\hline Disease & Animal model & Laser specifications & Irradiation condition & Measured parameters & References \\
\hline \multirow[t]{2}{*}{$A R$} & $\begin{array}{l}\text { Ovabumin induced AR } \\
\text { mouse (Balb/c) }\end{array}$ & $\begin{array}{l}658 \mathrm{~nm} \text { wavelength, } \\
30 \mathrm{~mW} \text { power output }\end{array}$ & $\begin{array}{l}1 \mathrm{~J} / \mathrm{cm}^{2}, 2 \mathrm{~J} / \mathrm{cm}^{2} \\
\text { continuous irradiation }\end{array}$ & $\begin{array}{l}\text { - Total IgE, IL-4 } \\
\text { - Thymus and activation regulated chemokine }\end{array}$ & Choi et al. $^{15}$ \\
\hline & $\begin{array}{l}\text { Ovalbumin induced AR } \\
\text { mouse (Balb/c) }\end{array}$ & $\begin{array}{l}650 \mathrm{~nm} \text { wavelength, } \\
5 \mathrm{~mW} \text { power output }\end{array}$ & $\begin{array}{l}15 \text { min /day, } \\
\text { continuous irradiation } \\
\text { with straight/diffusion } \\
\text { type fibers }\end{array}$ & $\begin{array}{l}\text { - Allergic symptoms } \\
\text { - Serum immunoglobulin levels } \\
\text { - Eosinophilic infiltration in the nasal mucosa and } \\
\text { cervical lymph nodes } \\
\text { - Systemic/local cytokine levels }\end{array}$ & Bae et al. ${ }^{19}$ \\
\hline \multirow[t]{2}{*}{$\begin{array}{l}\text { Allergic } \\
\text { asthma }\end{array}$} & $\begin{array}{l}\text { Ovalbumin induced } \\
\text { allergic asthma rats }\end{array}$ & $\begin{array}{l}810 \mathrm{~nm} \text { wavelength, } \\
80 \mathrm{~mW} \text { power output }\end{array}$ & $8 \mathrm{~J} / \mathrm{cm}^{2}$ for 21 days & $\begin{array}{l}\text { - Pathological damage/airway inflammation } \\
\text { - Total numbers of cells/eosinophils in BAL fluid } \\
\text { - Serum immunoglobulin/cytokine levels }\end{array}$ & Wang et al. ${ }^{20}$ \\
\hline & $\begin{array}{l}\text { HDM induced } \\
\text { allergic asthma mouse }\end{array}$ & $\begin{array}{l}660 \mathrm{~nm} \text { wavelength, } \\
100 \mathrm{~mW} \text { power output }\end{array}$ & $1,3,5$, and $7.5 \mathrm{~J}$ & $\begin{array}{l}\text { - Pathological airway inflammation } \\
\text { - Total numbers of cells in BAL fluid } \\
\text { (neutrophils, eosinophils, and T lymphocytes) } \\
\text { - Serum cytokine levels }\end{array}$ & $\begin{array}{l}\text { Rigonato- } \\
\text { Oliveira et al. }\end{array}$ \\
\hline
\end{tabular}

AR, allergic rhinitis; BAL, bronchoalveolar lavage; HDM, house dust mite; IL, interleukin. 
nitric oxide (NO) levels. The ROS and NO levels in lymph node (LN) cells and the nasal mucosa were reduced by LLLT, suggesting involvement of ROS and NO within their mechanism.

\section{Laser treatment in allergic asthma animal mod- els}

AR and allergic asthma have similar pathophysiology. The effect of laser treatment in animal models of allergic asthma also has been studied (Table 1). Here, we introduce several studies evaluated effects of LLLT in allergic asthma animal models.

Wang et al. investigated the effect of LLLT on allergic asthma in rats and compared its effect with that of the glucocorticoid (budesonide). ${ }^{20}$ Ovalbumin-induced allergic asthma rats were treated with LLLT $(810 \mathrm{~nm}, 80 \mathrm{~mW}$, $8 \mathrm{~J} / \mathrm{cm}^{2}$ for 21 days) or budesonide suspension. LLLT had a similar effect to that of budesonide. LLLT could relieve pathological damage and airway inflammation in asthmatic rats. LLLT also decreased the total numbers of cells and eosinophils in bronchoalveolar lavage (BAL) fluid. LLLT also reduced levels of IL-4 and increased interferon (IFN)-y levels in BAL fluid and serum, meanwhile reduced serum lgE levels. Flow cytometry assay showed that LLLT regulate the Th1/Th2 imbalance of asthmatic rats.

Another study evaluated the effect of LLLT (wavelength of $660 \mathrm{~nm}$, power of $100 \mathrm{~mW}$, energy of $1 / 3 / 5 / 7.5 \mathrm{~J}$ ) on chronic pulmonary inflammation in mouse model of asthma induced by house dust mite (HDM). ${ }^{21}$ The LLLT was able to modulate the pulmonary inflammation by reducing the number of cells in BAL fluid and reducing the percentage of neutrophils, eosinophils and T lymphocytes. On the other hand, LLLT increased the level of IL-10 and reduced levels of IL-4, IL-5 and IL-13 in BAL fluid. LLLT was also able to reduce the production of mucus, peribronchial eosinophils, collagen deposition, bronchoconstriction index, and bronchial and muscular thickening in the airways. In this study, while four different energies (1 J, $3 \mathrm{~J}, 5 \mathrm{~J}$, and $7.5 \mathrm{~J}$ ) were used, $1 \mathrm{~J}$ and $3 \mathrm{~J}$ laser presented better results.

\section{CLINICAL STUDIES OF PHOTOTHERAPY IN AR PATIENTS}

In a meta-analysis study, Cho et al. systematically reviewed the efficacy of endonasal phototherapy for improving the AR symptoms. ${ }^{22} \mathrm{~A}$ total of 13 trials met the inclusion criteria of this study, with a total sample size of 679 patients. Total 10 studies compared total nasal symptom scores (TNSS) before and after intranasal phototherapy. TNSS and individual nasal symptoms (nasal itching, obstruction, rhinorrhea, and sneezingl showed significant improvements after intranasal phototherapy. Improvements in disease-specific quality of life after intranasal phototherapy were evaluated in 4 studies: sleep, problems in practical issues, non-hay fever symptoms, nasal symptoms, limitation in activity, eye symptoms, and emotional problems significantly improved after intranasal phototherapy. Six studies involved a comparison of the reduction in nasal symptom scores between phototherapy treatment and a control. Control groups were divided in two groups: sham (4 studies) or antihistamine group (2 studies). Phototherapy significantly reduced the nasal itching, nasal obstruction, and rhinorrhea compared with the antihistamine group. However, no differences were detected in sneezing or total symptom score. In four studies, phototherapy significantly reduced all symptom scores compared with the sham group.

\section{mUV/VIS phototherapy of AR}

Many clinical studies evaluated the therapeutic effect of phototherapy in AR patients (Table 2). Rhinolight (Rhinolight Ltd., Szeged, Hungary) is an intranasal phototherapy device for AR (5\% UV-B, 25\% UV-A, 70\% visible light). ${ }^{23}$ Several randomized controlled trials evaluated the therapeutic effect of Rhinolight.

In a randomized, controlled, double-blind study, 49 patients with AR (ragweed-induced) who were unresponsive to medications were investigated. ${ }^{13}$ Intranasl phototherapy using Rhinolight resulted in a significant improvement of clinical symptoms for sneezing, rhinorrhea, nasal itching, and TNSS while none of the scores significantly improved in the control group. In the nasal lavage samples, phototherapy also significantly reduced the number of eosinophils and the level of eosinophil cationic protein and IL-5 in the treatment group.

In another randomized controlled trial, therapeutic effect of Rhinolight was evaluated in 62 patients with moderate to severe persistent AR. ${ }^{24}$ Treatments lasted 2 to 3 minutes. Each nasal cavity was irradiated 3 times a week for 2 weeks with increasing doses (from $1.6 \mathrm{~J} / \mathrm{cm}^{2}$ to $2.4 \mathrm{~J}$ / $\mathrm{cm}^{2}$ ). For the control group, a filter was used to cut out UV light, leaving only visible light. The authors evaluated the level of response to treatment in two groups and compared them according to TNSS and global severity scores (GSS) and rhinoconjunctivitis quality of life questionnaires (RQLQ) symptom scores. All these symptoms scores were significantly improved in treatment group compared to control group. 
Table 2. Clinical studies evaluated efficacy of phototherapy in allergic rhinitis patients

\begin{tabular}{|c|c|c|c|c|}
\hline Study design & Laser & Irradiation condition & Measured parameters & References \\
\hline $\begin{array}{l}\text { Randomized, } \\
\text { controlled trial }(\mathrm{N}=49)\end{array}$ & $\begin{array}{l}\text { Rhinolight } \\
\text { (5\% UV-B, 25\% UV-A, } \\
70 \% \text { visible light) }\end{array}$ & $\begin{array}{l}\text { Intranasal, } \\
3 \text { times/week for } 3 \text { weeks }\end{array}$ & $\begin{array}{l}\text { Clinical AR symptoms (TNSS) } \\
\text { Nasal lavage samples: number of eosinophils, } \\
\text { eosinophilc cationic protein level, IL-5 }\end{array}$ & Koreck et al. ${ }^{13}$ \\
\hline $\begin{array}{l}\text { Randomized, } \\
\text { controlled trial ( } \mathrm{N}=62)\end{array}$ & Rhinolight & $\begin{array}{l}\text { Intranasal, } \\
3 \text { times/week for } 2 \text { weeks }\end{array}$ & $\begin{array}{l}\text { Clinical AR symptoms, quality of life score } \\
\text { (TNSS, GSS, ROLO) }\end{array}$ & Soheila et al. ${ }^{24}$ \\
\hline $\begin{array}{l}\text { Randomized, } \\
\text { controlled trial }(\mathrm{N}=77)\end{array}$ & Rhinolight & $\begin{array}{l}\text { Intranasal, } \\
3 \text { times/week for } 2 \text { weeks }\end{array}$ & $\begin{array}{l}\text { Clinical AR symptoms, quality of life score } \\
\text { (TNSS, ROLO) } \\
\text { Nasal resistance }\end{array}$ & Albu et al. ${ }^{25}$ \\
\hline Case series $(\mathrm{N}=17)$ & PUVA & $\begin{array}{l}\text { Intranasal } \\
4 \text { times/week for } 3 \text { weeks }\end{array}$ & $\begin{array}{l}\text { Clinical AR symptoms (TNSS) } \\
\text { Allergen-induced wheal formation in the SPT reaction }\end{array}$ & Csoma et al. ${ }^{26}$ \\
\hline Case series $(\mathrm{N}=18)$ & $308 \mathrm{~nm} \mathrm{XeCl} \mathrm{UVB} \mathrm{laser}$ & $\begin{array}{l}\text { Intranasal } \\
2 \text { times/week for } 2 \text { weeks }\end{array}$ & $\begin{array}{l}\text { Clinical AR symptoms (TNSS) } \\
\text { Allergen-induced wheal formation in the SPT reaction }\end{array}$ & Csoma et al. ${ }^{29}$ \\
\hline $\begin{array}{l}\text { Randomized, } \\
\text { controlled trial } \\
(\mathrm{N}=101)\end{array}$ & $\begin{array}{l}\text { SN-206 } \\
\text { (652/940 nm wavelength) }\end{array}$ & $\begin{array}{l}\text { Intranasal } \\
3 \text { times/day for } 2 \text { weeks }\end{array}$ & $\begin{array}{l}\text { Symptom scores (sneezing/itching) } \\
\text { ECP levels } \\
\text { Nasal flow readings }\end{array}$ & Emberlin et al. $^{30}$ \\
\hline $\begin{array}{l}\text { Randomized, } \\
\text { controlled trial ( } N=79)\end{array}$ & $\begin{array}{l}\text { Bionase unit } \\
(660 \pm 5 \mathrm{~nm} \text { wavelength) }\end{array}$ & $\begin{array}{l}\text { Intranasal, } \\
3 \text { times/day for } 2 \text { weeks }\end{array}$ & $\begin{array}{l}\text { Improvement of AR symptoms (nasal obstruction, } \\
\text { rhinorrhea, edema of middle turbinate, nasal itching, } \\
\text { headache, cough (postnasal drip)) }\end{array}$ & Neuman et al. ${ }^{31}$ \\
\hline
\end{tabular}

AR, allergic rhinitis; TNSS, total nasal symptom score; GSS, global severity score; RQLQ, rhinoconjunctivitis quality of life questionnaire; PUVA, photochemotherapy with 8-methoxypsoralen (8-MOP) plus UVA light; SPT, skin prick test; ECP, eosinophilic cationic protein.

Albu et al. compared the efficacy of intranasal Rhinolight treatment with antihistamine medication (azelastine) in patients with $A R{ }^{25}$ Subjective and objective outcomes were represented by changes in TNSS, RQLQ, and nasal resistance. Both azelastine and intranasal phototherapy are able to improve TNSS significantly, including individual nasal symptoms. Rhinolight reduced nasal obstruction better than azelastine ( $p=0.038$ ). In improving RQLQ scores, both treatments were highly effective overall and in seven separate domains.

\section{UVA phototherapy of AR}

UVA light with 8-methoxypsoralen (8-MOP) (PUVA) has been widely used for the management of inflammatory skin diseases. It has the advantage of deeper tissue penetration compared to UVB light. Effectiveness of intranasal PUVA therapy in AR patients in an open study. ${ }^{26}$ PUVA treatment was performed by using a nasal spray containing 8-MOP at 2 minutes before irradiation of the nasal cavity and enrolled patients received four treatments a week for 3 weeks. Improvements were observed in all nasal symptoms (sneezing, rhinorrhea, nasal itching and nasal blockingl and also in TNSS.

\section{UVB phototherapy of AR}

Initially, broad-band UVB light sources $(290-320 \mathrm{~nm})$ were used for the treatment of allergic and non-allergic skin diseases. The "super narrow band" $308 \mathrm{~nm}$ xenon chloride (XeCl) laser was proved to be more effective than narrow band UVB both clinically and in its potential to induce T cell apoptosis. ${ }^{10,27,28}$

In one study, the efficacy of $308 \mathrm{~nm}$ UVB XeCl laser (Lambda Physics LPX 105 E, Göttingen, Germany) in 18 patients with moderate to severe ragweed induced AR who were not responsive to conventional treatments. ${ }^{29}$ One group received low-dose XeCl laser irradiation (starting dose: $0.25 \times$ minimal erythema dose (MED)), two treatments were given weekly for two weeks. Another group patients were treated with medium dose UVB (starting dose: $0.4 \times$ UVB), four treatment were given weekly for two weeks. In the low dose treatment group, no significant improvement of nasal symptoms or TNSS was observed. In the medium-dose treated group significant group, improvement of sneezing, rhinorrhea, nasal blockage and TNSS was achieved at the end of the treatment period.

\section{Red light, infrared phototherapy of AR}

Emberlin and colleagues investigated therapeutic effect of SN-206 (Lloyds Pharmacy Ltd., Warrington, United Kingdom) in patients with a history of hay fever in the grass pollen season with a double-blinded placebo controlled clinical study. ${ }^{30}$ This device (SN-206) emits infrared light (652 nm and $940 \mathrm{~nm}$ wavelength), delivering $0.54 \mathrm{~J} /$ $\mathrm{cm}^{2}$ per 3-minute cycle. Patients were told to use the device for 3 minutes 3 times a day, 5 to 6 hours apart for 14 
days before the pollen challenge. An allergen challenge of grass pollen was then delivered to the nostrils. Significant reductions in severity of symptom scores were found for sneezing, running nose, running eyes and itchy mouth/ palate. However, there was no significant differences in the results for itchy eyes/nose/throat.

A randomized controlled trial conducted in 1997 evaluated therapeutic effect of intranasal phototherapy on 79 perennial AR patients. ${ }^{31}$ The device used for this study was a Bionase unit (Amcor Ltd., Zürich, Switzerland) which emits red light at wavelength of $660 \pm 5 \mathrm{~nm}$. Patients received intranasal illumination for 4.4 minutes three times a day for 14 days (total dose $6 \mathrm{~J} /$ day). Significant improvement of symptoms was reported by $72 \%$ of the allergic rhinitis patients and objective improvement was endoscopically demonstrated in $70 \%$ of them as compared with $24 \%$ and $3 \%$, respectively, in the placebo group.

\section{Side effects of phototherapy}

In terms of safety issue, most reported side effects were mild and controllable. In one study, intranasal phototherapy with Rhinolight had mild dryness of the nasal mucosa which resolved after treatment with nasal drops in 3 patients out of total 25 patients. ${ }^{32}$ Two patients had mild nosebleed when blowing the nose in each treatment and control group. One patient in each group had headache and diarrhea. Temporary and spontaneously resolving nasal pain was reported by 3 patients in the phototherapy group and 2 in the placebo group. However, in other randomized controlled studies, dryness was the only side effect reported in the phototherapy (Rhinolight) group. ${ }^{25,33}$ No side effect other than dryness of the nasal mucosa was reported in clinical studies with other phototherapy devices. ${ }^{26,29-31}$

As phototherapy can leads to DNA damage, malignant transformation can be triggered if the damage is not repaired. Thus, development of skin cancers has always been a concern when applying long time phototherapy in patients with skin diseases. However, no significant increase in the risk of developing skin cancer was found in an extensive literature search. ${ }^{34}$ Since phototherapy or photochemotherapy of the nasal mucosa requires much lower cumulative dose than the threshold for increased cancer risk in the skin, the probability of carcinogenesis in the present therapeutic scheme is low.

\section{CONCLUSIONS}

Phototherapy is a novel, promising therapeutic modality for AR. Multiple studies demonstrated that phototherapy is able to suppresses the effector phase of the allergic reaction. Intranasal phototherapy results in significant improvement of clinical AR symptoms. Although antihistamines and local steroids are used with good results, there are cases in which complete resolution of the symptoms cannot be obtained. Moreover, the use of these drugs is controversial in special subsets of patients such as pregnant and breast-feeding women.

All these characteristics of AR highlight the need for effective new treatment options. Therefore, intranasal phototherapy may represent an alternative treatment of AR. Thus, Kemeny and Koreck ${ }^{35}$ recommended the addition of intranasal phototherapy into the treatment guideline for those patients with AR, who do not respond well to the conventional antihistamine and intranasal corticosteroids treatments, or for those who cannot take the suggested medication. In addition, phototherapy might be also considered as a future therapeutic approach in other inflammatory and immune mediated mucosal diseases.

\section{FINANCIAL DISCLOSURE}

The author has no financial interests related to the content of this article. No outside funding was received.

This research was supported by Basic Science Research Program through the National Research Foundation of Korea (NRF) funded by the Ministry of Science, ICT \& Future Planning (2019R1F1A1060589) and funded by the Ministry of Education (2018R1D1A3B07048683). This research was supported by Basic Science Research Program through the National Research Foundation of Korea (NRF) funded by the Ministry of Education (NRF2020R1A6A1A03043283).

\section{CONFLICT OF INTEREST}

The authors declared no potential conflicts of interest with respect to the research, authorship and/or publication of this article.

\section{REFERENCES}

1. Kay AB. Allergy and allergic diseases. First of two parts. N Engl J Med 2001;344:30-7.

2. Bousquet J, Van Cauwenberge P, Khaltaev N. Allergic rhinitis and its impact on asthma. J Allergy Clin Immunol 2001;108(5 Suppl):S147-334.

3. Nathan RA. The burden of allergic rhinitis. Allergy Asthma Proc 2007;28:3-9.

4. Hore I, Georgalas C, Scadding G. Oral antihistamines for the 
symptom of nasal obstruction in persistent allergic rhinitis--a systematic review of randomized controlled trials. Clin Exp Allergy 2005;35:207-12.

5. Lockey RF. Rhinitis medicamentosa and the stuffy nose. J Allergy Clin Immunol 2006;118:1017-8.

6. Salib RJ, Howarth PH. Safety and tolerability profiles of intranasal antihistamines and intranasal corticosteroids in the treatment of allergic rhinitis. Drug Saf 2003;26:863-93.

7. Ullrich SE, Alcalay J, Applegate LA, Kripke ML. Immunosuppression in phototherapy. Ciba Found Symp 1989;146:131-9; discussion 139-47.

8. Scheinfeld NS, Tutrone WD, Weinberg JM, DeLeo VA. Phototherapy of atopic dermatitis. Clin Dermatol 2003;21:241-8.

9. Jekler J, Larkö O. Combined UVA-UVB versus UVB phototherapy for atopic dermatitis: a paired-comparison study. J Am Acad Dermatol 1990;22:49-53.

10. Bónis B, Kemény L, Dobozy A, Bor Z, Szabó G, Ignácz F. 308 nm UVB excimer laser for psoriasis. Lancet 1997;350:1522.

11. Vermeer BJ, Hurks M. The clinical relevance of immunosuppression by UV irradiation. J Photochem Photobiol B 1994;24:149-54.

12. Monfrecola G, de Paulis A, Prizio E, Russo I, Carfora M, Santoianni $P$, et al. In vitro effects of ultraviolet $A$ on histamine release from human basophils. J Eur Acad Dermatol Venereol 2003;17:646-51.

13. Koreck Al, Csoma Z, Bodai L, Ignacz F, Kenderessy AS, Kadocsa E, et al. Rhinophototherapy: a new therapeutic tool for the management of allergic rhinitis. J Allergy Clin Immunol 2005; 115:541-7.

14. Krönauer C, Eberlein-König B, Ring J, Behrendt H. Influence of UVB, UVA and UVA1 irradiation on histamine release from human basophils and mast cells in vitro in the presence and absence of antioxidants. Photochem Photobiol 2003;77:531-4.

15. Choi B, Chang MS, Kim HY, Park JW, Ryu B, Kim J. Effects of low level laser therapy on ovalbumin-induced mouse model of allergic rhinitis. Evid Based Complement Alternat Med 2013;2013:753829.

16. MacLean JA, Sauty A, Luster AD, Drazen JM, De Sanctis GT. Antigen-induced airway hyperresponsiveness, pulmonary eosinophilia, and chemokine expression in B cell-deficient mice. Am J Respir Cell Mol Biol 1999;20:379-87.

17. Williams CM, Galli SJ. Mast cells can amplify airway reactivity and features of chronic inflammation in an asthma model in mice. J Exp Med 2000;192:455-62.

18. Mo JH. Principles and application of mouse model of allergic rhinitis. Korean J Otorhinolaryngol-Head Neck Surg 2015;58:159-65.

19. Bae JS, Kim SH, Kim JH, Kim EH, Lyu L, Chung PS, et al. Effects of low-level laser irradiation in a mouse model of allergic rhinitis. Lasers Surg Med 2020;52:347-57.
20. Wang XY, Ma WJ, Liu CS, Li YX. Effect of low-level laser therapy on allergic asthma in rats. Lasers Med Sci 2014;29:1043-50.

21. Rigonato-Oliveira NC, de Brito AA, Vitoretti LB, de Cunha Moraes G, Gonçalves T, Herculano KZ, et al. Effect of LowLevel Laser Therapy (LLLT) in pulmonary inflammation in asthma induced by House Dust Mite (HDM): dosimetry study. Int J Inflam 2019;2019:3945496.

22. Cho HK, Jeong YM, Lee HS, Lee YJ, Hwang SH. Efficacy of endonasal phototherapy for relieving the symptoms of allergic rhinitis: meta-analysis. Am J Rhinol Allergy 2015;29:283-91.

23. Brehmer D. Endonasal phototherapy with Rhinolight for the treatment of allergic rhinitis. Expert Rev Med Devices 2010;7:21-6.

24. Alyasin S, Nabavizadeh SH, Houshmand H, Esmaeilzadeh $H$, Jelodar S, Amin R. Short time efficiency of rhinophototherapy in management of patients with allergic rhinitis resistant to medical therapy. Iran J Allergy Asthma Immunol 2016;15:317-27.

25. Albu S, Baschir S. Intranasal phototherapy versus azelastine in the treatment of seasonal allergic rhinitis. Auris Nasus Larynx 2013;40:447-51.

26. Csoma Z, Koreck A, Ignacz F, Bor Z, Szabo G, Bodai L, et al. PUVA treatment of the nasal cavity improves the clinical symptoms of allergic rhinitis and inhibits the immediate-type hypersensitivity reaction in the skin. J Photochem Photobiol B 2006;83:21-6.

27. Trehan M, Taylor CR. High-dose 308-nm excimer laser for the treatment of psoriasis. J Am Acad Dermatol 2002;46:732-7.

28. Baltás E, Csoma Z, Ignácz F, Dobozy A, Kemény L. Treatment of vitiligo with the 308-nm xenon chloride excimer laser. Arch Dermatol 2002;138:1619-20.

29. Csoma Z, Ignacz F, Bor Z, Szabo G, Bodai L, Dobozy A, et al. Intranasal irradiation with the xenon chloride ultraviolet $B$ laser improves allergic rhinitis. J Photochem Photobiol B 2004; 75:137-44.

30. Emberlin JC, Lewis RA. Pollen challenge study of a phototherapy device for reducing the symptoms of hay fever. Curr Med Res Opin 2009:25:1635-44.

31. Neuman I, Finkelstein Y. Narrow-band red light phototherapy in perennial allergic rhinitis and nasal polyposis. Ann Allergy Asthma Immunol 1997;78:399-406.

32. Bella Z, Kiricsi Á, Viharosné ÉD, Dallos A, Perényi Á, Kiss M, et al. Rhinophototherapy in persistent allergic rhinitis. Eur Arch Otorhinolaryngol 2017;274:1543-50.

33. Cingi C, Cakli H, Yaz A, Songu M, Bal C. Phototherapy for allergic rhinitis: a prospective, randomized, single-blind, placebocontrolled study. Ther Adv Respir Dis 2010;4:209-13.

34. Lee E, Koo J, Berger T. UVB phototherapy and skin cancer risk: a review of the literature. Int J Dermatol 2005;44:355-60.

35. Kemény L, Koreck A. Ultraviolet light phototherapy for allergic rhinitis. J Photochem Photobiol B 2007;87:58-65. 
How to cite this article: Yoo SH, Chung YJ, Bae JS, Mo JH. Phototherapy in allergic rhinitis: from in vitro studies to clinical trials. Med Lasers 2020;9:95-102. https://doi.org/10.25289/ ML.2020.9.2.95 